DOI

\title{
ІНФОРМАЦІЙНО-СТРУКТУРНА МОДЕЛЬ АДАПТИВНОЇ КОРЕКЦІї РУХОВОї АКТИВНОСТІ дитини
}

\author{
ФГ. С. Лепьохіна', С. М. Злепко², О. Ю. Азархов \\ Скадовська чентральна районна лікарня \\ Вінницький національний технічний університет \\ Приазовський державний технічний університет ${ }^{3}$
}

РЕЗЮМЕ. В статті розглянуто шляхи і побудовано інформаційно-структурну модель адаптивної корекції рухової активності дитини; проаналізовано потоки даних, пов'язаних із індивідуалізацією призначення і вибору параметрів управляючих впливів для корекції рухових розладів у дітей в перинатальному періоді за допомогою функціонального біоуправління. Показано, що управління руховою діяльністю здійснюється за допомогою двоконтурної ієрархічної системи, в якій відновлення порушених функцій здійснюється шляхом вироблення нового динамічного стереотипу.

Мета дослідження. Підвищення ефективності лікування дітей з руховими порушеннями шляхом побудови інформаційно-структурної моделі адаптивної корекції рухової активності дитини.

Особливістю розробленої моделі $\epsilon$ визначення «фонового» стану м'яза і введення інструментального контролю його стомлюваності в процесі сеансу біоуправління. Це забезпечує формування лікарем індивідуальної програми адаптивної корекції рухових розладів дитини з урахуванням ії функціонального стану, загрози виникнення ускладнень, що є основою для прийняття остаточного рішення стосовно тактики лікування.

КЛЮЧОВІ СЛОВА: інформаційна модель, рухова активність, функціональне біоуправління, алгоритм, синдром, адаптивна корекція, управляючі впливи, стан м'яза.

Вступ. Вирішення багатопланових завдань спостереження за хворими з поєднаною патологією і робота з їх реабілітації і соціальної адаптації найефективніше може здійснюватися при наявності комп'ютерної інформаційної підтримки завдань, коли в рамках єдиної системи забезпечується інтеграція поточної медичної інформації про пацієнта; обмін даними щодо проведеного лікування / реабілітації в різних 303; рекомендації по етапних заходах психолого-педагогічного характеру; дані для ухвалення соціальних рішень; аналіз ефективності лікувально-реабілітаційних заходів і прогноз перебігу, а також запобігання рецидивам захворювання після проведеного лікування [1-3].

Матеріал і методи дослідження. При виборі оптимальної тактики адаптивної корекції (АК) [3] рухової активності дитини з передбачуваною позитивною динамікою необхідно враховувати цілий ряд анамнестичних, функціональних, лікувально-діагностичних та інших факторів (показників), і насамперед індивідуальні особливості конкретної дитини.

В узагальненому вигляді схему потоків даних, індивідуалізації вибору і призначення управляючих впливів можна представити наступним чином (рис. 1).

На основі вихідних даних дитини (анкетних, антропометричних, анамнестичних, результатів попередніх біохімічних досліджень, фізіологічних і функціональних обстежень) та результатів останніх досліджень, проведених, при необхідності, за місцем лікування, в т.ч. серцево-судинної, нейрогуморальної, центральної і периферійної нервової системи, формується попередній висновок про поточний стан дитини, який заноситься до бази даних. Діагностика функціонального стану ураженої частини тіла дитини та пов'язаних з цим порушень дає лікарю інформацію про складність і зворотність патологічного процесу та більш чітко окреслює область впливу при подальшому лікуванні.

Особливо важливо при цьому враховувати психологічний стан дитини, її початкову мотивацію на одужання, внутрішню силу і зацікавленість у досягненні певних позитивних зрушень, досить часто незначної, але позитивної динаміки та утримувати цю психоемоційну налаштованість.

Для ефективного управління руховою діяльністю необхідно визначитись з руховою задачею, тобто створити образ бажаного майбутнього, який, окрім нього, одночасно містить у собі образ минулого та образ теперішнього. Його створення стає можливим тільки на основі екстраполяції того, що відбирається мозком з образів післядії, утворених за участю орієнтувально-пошукових реакцій [3]. Цей процес багаторівневий і має складну ієрархічну будову. Основою орієнтувальної діяльності індивіда $\epsilon$ безумовно рефлекторна орієнтація та мимовільна організація діяльності на рівні відчуттів.

Можна також вважати, що функціонування механізмів управління рухами відбувається циклічно: від механізму формування ставлення індивіда до ситуації, яка пред'являється, до 


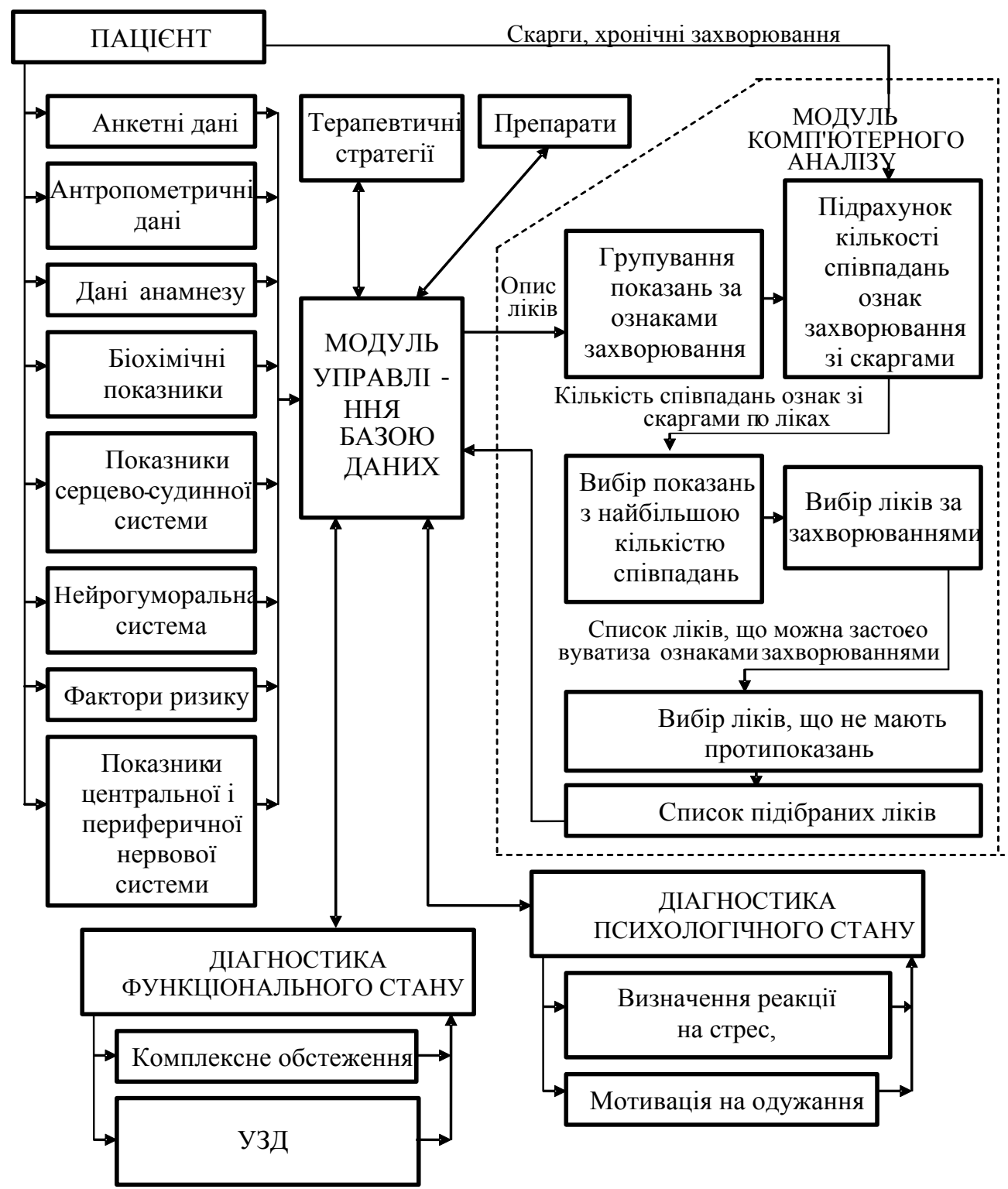

Рис. 1. Схема потоків даних індивідуалізації вибору і призначення управляючих впливів.

механізму, що задає, програмує, зіставляє і забезпечує внесення корекцій. Основу функціонування цих механізмів становить орієнтувальнопошукова діяльність, яка щоразу поновлюється при виявленні розбіжностей між завданням і результатом дії на кожному з етапів. Орієнтувально-пошукова діяльність опосередковано впливає на успішність управління, стимулюючи неспецифічну активність ЦНС, що забезпечує більш ретельний аналіз навколишнього середовища та ефективне отримання інформації з довготривалої пам'яті [4].

Це підтверджує те, що управління руховою діяльністю може здійснюватися за допомогою двоконтурної багаторівневої ієрархічної циклічної функціональної системи, при якій компенсація порушених функцій здійснюється шляхом пе- ребудови старого і вироблення нового динамічного стереотипу [5].

Результати й обговорення. Як правило, знаннями в подібних системах слугують відповідні функціональні алгоритми і моделі, що забезпечують прийняття рішень та управління відповідними процесами.

При побудові алгоритму управління адаптивною корекцією рухових розладів дитини бажано дотримуватись нижченаведеної послідовності процедур, що забезпечують його високу надійність, ефективність та адекватність. Першою процедурою $є$ реєстрація та інструментальний збір даних про функціональний стан пацієнта. Отримані дані обов'язково повинні містити окремим файлом дані про функціонально-фізіологічний стан ураженого м'яза або групи м'язів, який в подальшому, 
Огляди літератури, оригінальні дослідження, погляд на проблему

за аналогією з [6], буде визначатись як «фоновий» і відносно якого будуть здійснюватись усі наступні дії. Після отримання кількісної оцінки «фонового» стану формується тестовий сигнал, який через відповідні виконавчі пристрої подається на уражений м'яз або групу м'язів.

Наступна процедура являє собою аналіз параметрів відгуку на тестовий вплив, який лікар отримує від пацієнта через відповідні блоки системи. Відмінністю даного алгоритму $\epsilon$ те, що впродовж дії лікувального управляючого стимулу здійснюється інструментальний фізіологічний контроль за «втомою» стимульованого м'яза, що особливо важливо для дитини. Коли м'яз «стомлюється", його подальша стимуляція не тільки не корисна, а навіть шкідлива, тому, як тільки м'яз досягає рівня втоми, автоматично переривається подача стимулюючого впливу, про що свідчить відповідний сигнал. Після закінчення процедури стимуляції фактично відбувається перша процедура з різницею в тому, що функціональний стан дитини і фізіологічні параметри м'яза визначаються як «кореговані».

Порівняння всіх корегованих станів між собою і по відношенню до "фонового" дозволяє чітко визначити динаміку патофізіологічного процесу та оцінити якість, ефективність та адекватність призначених лікарських заходів і процедур.

Крім того, за допомогою даного алгоритму можна отримати стереотипні рухи, рівень і структура яких зумовлені індивідуальними особливостями, давністю та тяжкістю захворювання, супутніми патологіями та іншими чинниками і побудувати інформаційну модель адаптивної корекції рухової активності дітей з синдромом рухових розладів (рис. 2).

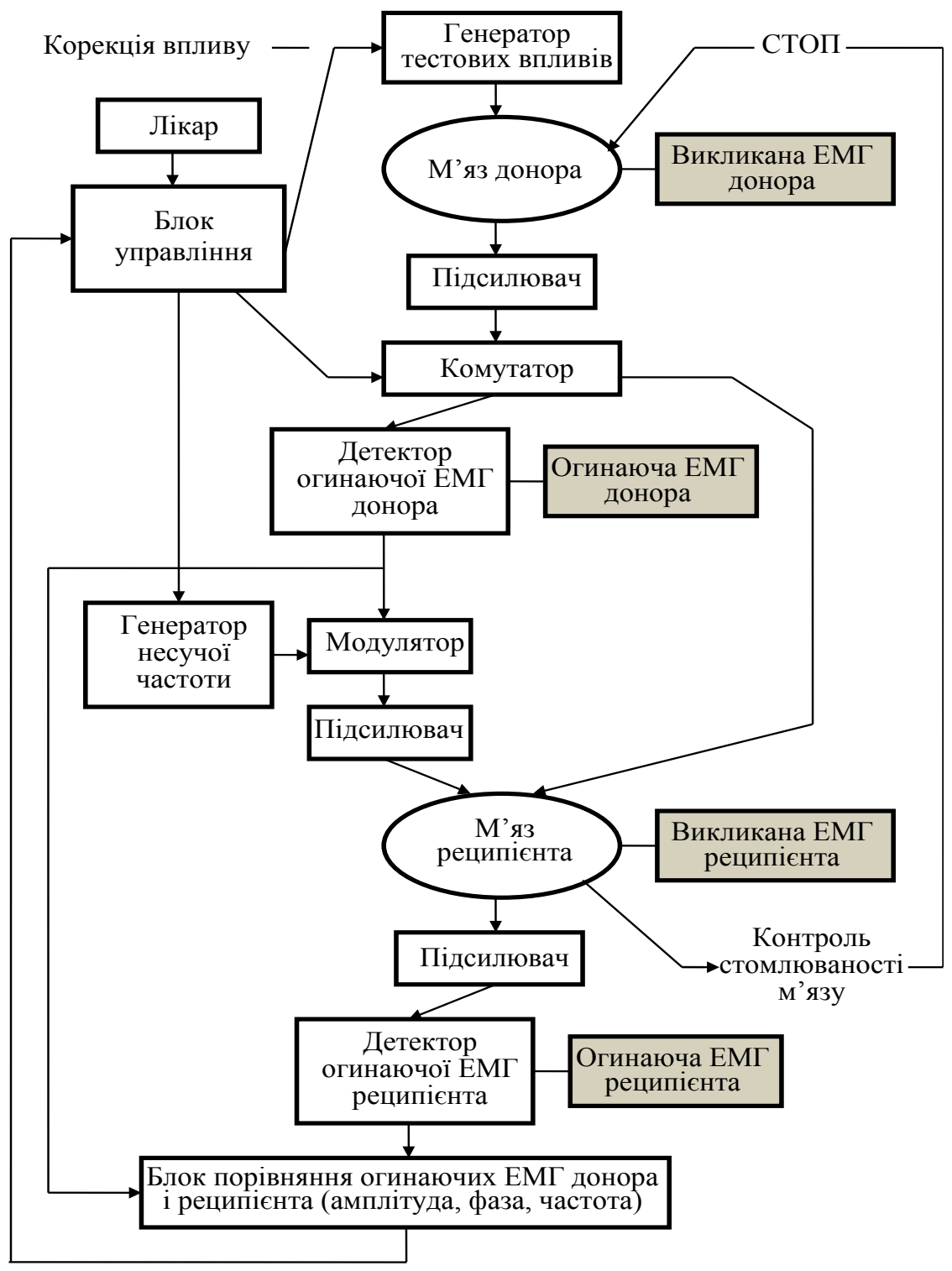

Рис. 2. Інформаційна модель адаптивної корекції рухової активності дітей з синдромом рухових розладів. 
Огляди літератури, оригінальні дослідження, погляд на проблему

Для проведення адаптивної корекції дитини необхідно визначити оптимальні параметри управляючих впливів, які в процесі реабілітації даватимуть стійкий позитивний динамічний результат. Для вибору цих індивідуальних для конкретної дитини параметрів лікувальних впливів необхідно подати на дитину тестовий вплив з метою подальшої його корекції та вибору найоптимальнішого режиму. Лікар, використовуючи блок управління та генератор тестових впливів, подає на м'яз донора лікувальний вплив для отримання викликаної ЕМГ і через підсилювач, комутатор і детектор отримує огинаючу ЕМГ донора. Параметри викликаної та огинаючої ЕМГ донора свідчать про кількісне та якісне співвідношення поданого тестового впливу. Відкорегований лікувальний вплив через генератор несучої частоти, модулятор, підсилювач та комутатор подається на м'яз реципієнта для реєстрації викликаної ЕМГ реципієнта, а через детектор - для отримання огинаючої ЕМГ реципієнта. При цьому здійснюється обов'язковий контроль стомлюваності м'яза, що суттєво зменшує небажану низьку ефективність лікувальних впливів та забезпечує отримання стійкого, більш тривалого терапевтичного ефекту. Високий рівень стомлюваності м'яза вимагає зупинки подачі лікувальних впливів з метою подальшої їх корекції.

Дані проведених тестових і лікувальних впливів надходять до блоку порівняння огинаючих ЕМГ донора та реципієнта, після чого до блоку управління надходить висновок про найоптимальніші адаптивні амплітудні, фазові, частотні та часові параметри лікувальних впливів.

Запропонована модель здійснює контроль і корекцію стану м'яза за вищезазначеним алгоритмом і забезпечує, аналогічно з $[3,5]$ :

- тренування згинаючих і розгинаючих рухів дистальних відділів кінцівок з метою покращення пропріоцептивної аферентації;

\section{ЛІТЕРАТУРА}

1. Сидорова И. С. Биофизический профиль плода при гестозе / И. С. Сидорова, И. О. Макаров, А. А. Блудов // Российский вестник перинатологии и педиатрии.1999. - Т. 44, № 1. - С. 14-20.

2. Ракитина Е. Применение метода функционального биоуправления при подготовке беременных к родам / Е. Ракитина // Институт интегративной семейной терапии [Электронный ресурс]. - Режим доступа: http:// www.family.ru/librery/publicarticle/publicarticle-276. html. - Дата обращения: 19.01.2016. - Название с экрана.

3. Антонюк Г. Н. Принципы формирования алгоритма управления лечебным процессом в неврологической практике и постинсультных больных с двигательными нарушениями / Г. Н. Антонюк, С. И. Гаркуша, Н. А. Максименко // В кн. Медицинская и физиологи-
- тренування великих розмашистих рухів, направлених на формування динамічного стереотипу;

- тренування окремих послаблених м'язів кисті, стопи та ін.;

- тренування "крокових» рухових навичок за спеціальною програмою;

- тренування мімічної мускулатури при різних невритах;

- формування повних або відновлення старих стереотипних рухів.

Додатковим елементом контролю, але вже загального стану пацієнта під час проведення процедури, $є$ контроль серцево-судинної діяльності за параметрами ЕКГ та артеріального тиску.

Наявність експертної системи обумовлена тим, що експертні процедури дозволяють враховувати приховані взаємозв'язки між показниками завдяки використанню досвіду, знань та інтуїції фахівців (експертів) у предметній області і сформувати такий перелік показників, який максимально адекватно відображає найбільш значимі аспекти корекції для кожної конкретної дитини.

Висновки. Використовуючи запропоновану модель лікар формує індивідуальну програму адаптивної корекції рухових розладів дитини 3 урахуванням ії функціонального стану, потенційних можливостей та загрози виникнення ускладнень і вже на цій основі приймає остаточне рішення стосовно тактики і стратегії адаптивної корекції. Для того, щоб точно визначити наявність потенційної загрози виникнення ускладнень, лікар використовує відповідну базу даних і підсистему підтримки прийняття рішень.

Перспективи подальших досліджень. Запропоновано продовжувати дослідження в частині розширення застосування розробленої моделі для лікування інших патологій дітей в перинатальному періоді життя

ческая кибернетика. - К. : ИК АН УССР, 1981. - С. 66-70.

4. Биоуправление в клинической практике // ООО Компьютерные системы биоуправления [Электронный ресурс]. - Режим доступа: http://www.boslab.ru/ methods/bioypravlenie/clinical_practice.php. - Дата обращения: 19.01.2016. - Название с экрана.

5. «Миотон» в управлении движениями / Л. С. Алеев, М. И. Вовк, В. Н. Горбанев, А. Б. Шевченко; [отв. ред. Д. А. Василенко]: АН УССР, Ин-т кибернеткики. - К. : Наукова думка, 1980. - 143 с.

6. Варежкин Ю. П. Влияние биоэлектрического управления на рефлекторную возбудимость альфа-мотонейронов спинного мозга / Ю. П. Варежкин, В. И. Клеринт // В кн. Медицинская и физиологическая кибернетика. - К. : ИК АН УССР, 1981. - С. 71-78. 
Skadovsk Central District Hospital

Vinnytsia National Technical University²

Pryazov State Technical University ${ }^{3}$

SUMMARY. In the article the information-structural model of the adaptive correction motor activity of the child was built. It was analyzed the data streams which are associated with the appointment of individualization and selection parameters of control actions to correct the movement disorders in children in the perinatal period using functional biofeedback. It is shown that control motor activity carried out by developing a new dynamic stereotype by using a two hierarchical system in which the renewal of the functions.

The peculiarity of the model is to determine the "background" of muscle condition and input tool control its fatigue during the session biofeedback. This provides the physician forming an individual program of adaptive correction of motor disorders of the child because of its functional state, the threat of complications, which is the basis for a final decision on treatment.

KEY WORDS: information model, physical activity, functional biofeedback algorithm syndrome, adaptive correction control influences muscle condition.

Отримано 25.06.2016 